\title{
Deterioration Characteristics of Cement-Limestone Powder Paste Under Compound Erosion Solution
}

\author{
Shuhua LIU ${ }^{1,2}$, Lu WANG ${ }^{1,2}$, Ningning HU ${ }^{1}$, Junwei SONG ${ }^{2}$ \\ ${ }^{1}$ State Key Laboratory of Water Resources and Hydropower Engineering Science, Wuhan University, Wuhan 430072, \\ China \\ ${ }^{2}$ Nanchang Key Laboratory of Material and Structure Detection, Jiangxi University of Technology, Nanchang 330098, \\ China \\ crossref http://dx.doi.org/10.5755/j01.ms.24.2.17644
}

Received 23 February 2017; accepted 05 July 2017

\begin{abstract}
The deterioration characteristics of cement-limestone powder paste under compound erosion solution were studied in this paper by determining the compressive and flexural strength of pastes, the hydration products and SEM micrographs. The results indicate that $\mathrm{H}^{+}$and $\mathrm{SO}_{4}{ }^{2-}$ ions play major roles in compound erosion solution. Besides the neutralization reaction between $\mathrm{H}^{+}$ions and $\mathrm{Ca}(\mathrm{OH})_{2}$, the reaction between $\mathrm{Ca}^{2+}$ ions and $\mathrm{SO}_{4}{ }^{2-}$ ions generates $\mathrm{CaSO}_{4} \cdot 2 \mathrm{H}_{2} \mathrm{O}$ and results in expansion. The crystal hydration products of all pastes before erosion are $\mathrm{Ca}(\mathrm{OH})_{2}$ and some $\mathrm{CaCO}_{3}$ from unhydrated limestone powder. While after erosion, the content of $\mathrm{CaCO}_{3}$ and $\mathrm{Ca}(\mathrm{OH})_{2}$ decreases rapidly and more gypsum forms. Limestone powder may improve the resistance to compound erosion sometimes. The resistance to compound erosion solution of compressive strength becomes weaker with the increase of the dosage of limestone powder (LP), while that of flexural strength becomes stronger. The compound erosion resistance is strong for the pastes with fly ash (FA) and LP, which can accelerate the compressive and flexural strength over curing age.

Keywords: limestone powder, paste, compound chemical erosion, deterioration characteristics.
\end{abstract}

\section{INTRODUCTION}

Concrete, the main cement-based material, is currently the most commonly used building material in the world, and this trend seems to last for this century due to its sufficient raw materials, low cost, ease of placement, and low maintenance [1]. At present, in order to reduce the consumption of Portland cement in engineering field, which is energy-intensive and is responsible for large quantities of $\mathrm{CO}_{2}$ emissions [2,3], more and more mineral admixtures are used as supplementary cementitious materials, such as ground granulated blast furnace slag (GGBS), fly ash, and silica fume [4-8]. The storage of traditional mineral admixtures reduces gradually and even gets a shortage with quick development of base infrastructures. Therefore, some new cementitious materials with large storage must be used to ease this situation.

Limestone powder is made up of ground limestone, which has easy access to. In concrete industry, limestone powder with high filling effect has been gradually applied into concrete due to its easily accessible, good quality and low cost [9-14]. On one hand, the usage of limestone powder from the exploitation of limestone can reduce the usage of Portland cement clinker, which can ease the shortage crisis of raw materials and contribute in sparing resources. On the other hand, the development of the green concrete will be promoted further. In Europe, it is very common to use limestone powder as mineral admixture in Portland cement, and the maximum limestone powder content reaches to $35 \%$. Meanwhile, the European Standard (EN 197-1:2011) has also identified Portland

\footnotetext{
${ }^{*}$ Corresponding author. Tel.: +86-27-68772233; fax: +86-27-68772310.

E-mail address: shliu@whu.edu.cn (S. Liu)
}

limestone cements, which achieves various technical, economic, and ecological benefits.

At the same time, water pollution of rivers and lakes in China becomes more and more serious, and the erosion irons in rainwater are common, which may lead to the damage and destroy of concrete structures. Therefore, the resistance to chemical attack of concrete structures is very important to fit in with the change of environment. For a long time, the destruction of cement-based materials caused by chemical erosion has been a prevalent issue to domestic and foreign scholars, even though some achievements have been made regarding chemical erosion over time. The most important one is the degradation mechanisms of various single chemical erosion of cementbased materials, such as sulfate attack, magnesium erosion, carbonation, and acid erosion [15-20]. However, there is less research on two or more chemical erosions of cementbased materials. The compound chemical erosion is very common in practice. By improving the compound erosion mechanism of cement-based materials, the durability will be enhanced, the service life will be prolonged and accurately predicted.

It is necessary to understand the deterioration of the cement-based materials under the compound chemical erosion when combined with actual production. Therefore, the deterioration characteristics of cement-limestone powder paste under compound erosion solution are studied in this paper.

\section{EXPERIMENTAL}

The chemical compositions of ordinary Portland cement (C), which is complied with the Chinese National Standard GB 175-2007, limestone powder (LP) and fly ash 
Table 1. Chemical compositions of the ordinary Portland cement, limestone powder and fly ash (mass, \%)

\begin{tabular}{|c|c|c|c|c|c|c|c|c|c|c|c|c|}
\hline Compositions & $\mathrm{SiO}_{2}$ & $\mathrm{Al}_{2} \mathrm{O}_{3}$ & $\mathrm{CaO}$ & $\mathrm{Fe}_{2} \mathrm{O}_{3}$ & $\mathrm{MgO}$ & $\mathrm{SO}_{3}$ & $\mathrm{~K}_{2} \mathrm{O}$ & $\mathrm{Na}_{2} \mathrm{O}$ & $\mathrm{TiO}_{2}$ & $\mathrm{MnO}$ & $\mathrm{P}_{2} \mathrm{O}_{5}$ & LOSS \\
\hline $\bar{C}$ & 28.25 & 4.46 & 58.77 & 3.24 & 0.4 & 3.36 & 1.12 & 0.26 & 0.33 & 0.04 & 0.17 & 2.78 \\
\hline LP & 2.50 & 0.60 & 54.03 & 0.36 & 0.54 & 0.01 & 0.10 & 0.08 & 0.05 & 0.54 & - & 41.59 \\
\hline FA & 61.30 & 24.10 & 2.20 & 3.79 & 1.43 & 1.39 & 3.00 & 0.42 & 0.87 & 0.05 & 0.15 & 1.30 \\
\hline
\end{tabular}

Table 2. Mix proportions of the pastes

\begin{tabular}{|c|c|c|c|c|c|}
\hline Samples & Water to binder ratio & Water & Cement & Limestone powder & Fly ash \\
\hline J-1 & 0.30 & 0.231 & 0.615 & 0.154 & - \\
\hline J-2 & 0.30 & 0.231 & 0.462 & 0.308 & - \\
\hline J-3 & 0.30 & 0.231 & 0.462 & 0.154 & 0.154 \\
\hline
\end{tabular}

(FA), which is conformed to the requirements of the secondary ash of the Chinese National Standard DL/T 5055-2007, determined by X-ray fluorescence (XRF) are listed in Table 1.

$\mathrm{LP}$ is rich in $\mathrm{CaO}$ and less $\mathrm{SiO}_{2}$, while $\mathrm{FA}$ is rich in $\mathrm{SiO}_{2}$ and less $\mathrm{CaO}$, both of which are different from those of $\mathrm{C}$. The mix proportions of the pastes are shown in Table 2. $40 \mathrm{~mm} \times 40 \mathrm{~mm} \times 160 \mathrm{~mm}$ cuboid cement pastes used in this paper are prepared by the paste mixer with water to binder ratio of 0.30 . All these paste samples are cured in normal environment with relative humidity $(\mathrm{RH})$ higher than $90 \%$ and temperature of $20 \pm 2{ }^{\circ} \mathrm{C}$ till the stipulated age of 180 days and then the flexural and compressive strength of the samples are tested respectively by anti-rupture test machine and compressive testing machine with battery solution type WAY-2000. Specific test procedure is referred to GB/T 17671-2005: Method of Testing Cement-Determination of Strength.

Then samples were divided into two groups. One group is soaked in the compound erosion solution, which is the experimental group. The other group soaked in saturated calcium hydroxide solution is the control group. The compound erosion solution is the mixture of $\mathrm{HCl}$ and $\mathrm{MgSO}_{4}$ with $\mathrm{MgSO}_{4}$ mass fraction $2 \%$. The initial $\mathrm{pH}$ value of the solution is 2 , and then changes the solution to new till the $\mathrm{pH}$ value up to 8 . In addition, whether in compound erosion solution or in saturated calcium hydroxide solution, all samples are required to below the liquid level $15 \mathrm{~cm}$. The flexural and compressive strength in erosion time 3, 7, 28, 60 and 90 days are tested and contrasted with the initial value. Then, the samples are broken and the small central parts of the samples are selected to be soaked in anhydrous ethanol to terminate the hydration for microstructure test SEM. The rest of sample central pieces are ground in the agate mortar and dried in $60{ }^{\circ} \mathrm{C}$ for 2 hours to reduce carbonization for XRD test and dried in vacuum condition for TG-DTA at respective ages.

The XRF experiments were done on Axios advanced $\mathrm{X}$-ray fluorescence instrument, in voltage range from 30 to $60 \mathrm{kV}$, with approximately $5 \mathrm{~g}$ of sample. XRD experiments were measured by X-ray Diffraction Analyzer with D/MAX-RB models of target X-ray diffraction, using copper target and continuous scan, produced by RIGAKU, a Japanese company. The TG-DTA experiments were measured on the Diamond TG/DTA analyzer, produced by Perkin Elmer Instruments Plant (Shanghai), in the temperature range from 20 to $1.000{ }^{\circ} \mathrm{C}$, using platinum crucibles with approximately $0.004 \mathrm{~g}$ of sample, under dynamic $\mathrm{N}_{2}$ atmosphere $(50 \mathrm{~mL} / \mathrm{min})$. Morphology of all products were investigated using a scanning electron microscopy with JSM-5610LV models.

\section{RESULTS AND DISCUSSION}

\subsection{Strength}

Fig. 1 clearly indicates the compressive and flexural strength development trends of all pastes at each erosion time. Both the compressive and flexural strength of the control group under the condition of saturated calcium hydroxide solution at every erosion time have no obvious fluctuation, while the changes of experimental group under the condition of compound erosion solution are distinct.

Fig. $1 \mathrm{a}$ and $\mathrm{b}$ show the compressive and flexural strength of paste sample J-1 with $20 \%$ LP and J-2 with $40 \%$ LP replaced of cement under the compound erosion and saturated calcium hydroxide solutions respectively.

Before the erosion time of 28 days, the compressive strength of samples $\mathrm{J}-1$ and $\mathrm{J}-2$ reduces, and then increases at later. It tends to be stable up to 60 days, which is higher than that of control group as well as the initial value. The compressive strength change range of sample J-2 is smaller than that of J-1, which means that the more LP content, the less influence on compressive strength. As the erosion time increases, flexural strength increases prior to 60 days, and falls sharply after 60 days. Up to 90 days, flexural strength is lower than that of control group, is also lower than the initial value.

Fig. $1 \mathrm{c}$ shows the compressive and flexural strength of paste sample J-3 with $20 \%$ LP and $20 \%$ FA replaced of cement under the compound erosion and saturated calcium hydroxide solutions. Its compressive strength increases and stabilizes after 60 days, while the later strength is always higher than that of control group and the initial value. The flexural strength increases fast before 28 days, then gets stable and reduces after 60 days, and the strength is lower than the initial value up until 90 days.

Compressive strength of the samples containing LP only reduces before the erosion time of 28 days, while increases at later, which indicates that the resistance to compound erosion at later can be improved by adding LP, which has the same result that there is not significant damage in any of mortars during being immersed in $\mathrm{Na}_{2} \mathrm{SO}_{4}, \mathrm{MgSO}_{4}$ and $\mathrm{NaCl}$ solutions [21]. Flexural strength increases at early, while decreases sharply at later. 


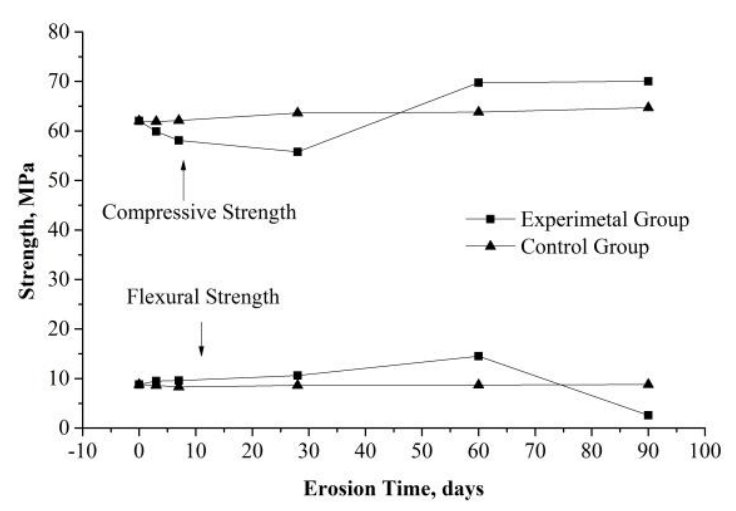

a

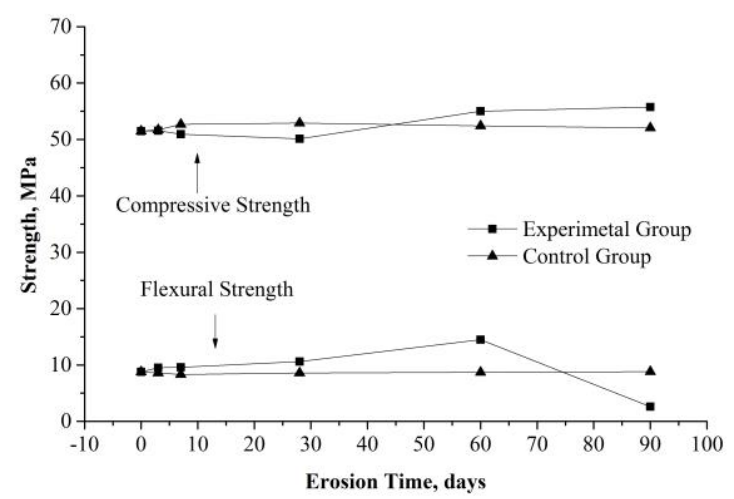

b

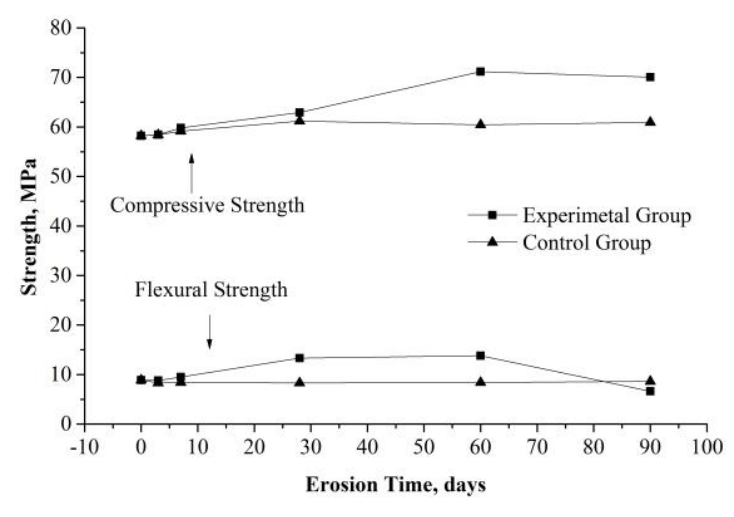

c

Fig. 1. Compressive and flexural strength over erosion time: $\mathrm{a}-\mathrm{J}-1 ; \mathrm{b}-\mathrm{J}-2 ; \mathrm{c}-\mathrm{J}-3$

Samples with high LP dosages can resist the compound erosion. At the early erosion time, there is little increase in compressive and flexural strength, but flexural strength decreases at later. The more LP content, the less the strength changes, which means that more LP dosage can stable the paste compressive strength at the level of control group. When the dosage of limestone powder replaced cement is $15 \%$, it can increase the durability of concretes submerged in magnesium sulphate solutions [22]. Compound erosion solution has great influence on flexural strength of the sample with LP and FA. At early, the flexural strength increases, and then decreases at later, while compressive strength continues to increase over time.

As shown in Fig. 2, when comparing sample $\mathrm{J}-2$ with $\mathrm{J}-1$, the compressive strength is lower all the time and the difference gradually increases after 60 days. Flexural strength decreases with the increase of LP content at early erosion time, especially for the J-2 sample with more LP content at 7 days. When comparing samples $\mathrm{J}-3$ and $\mathrm{J}-2$, FA can increase compressive strength over erosion time, but it has little effect on flexural strength. The decreasing range of flexural strength is very high up to the erosion time of 90 days. The higher the LP dosage, the weaker the resistance to the compound erosion for the compressive strength and the stronger the erosion resistance for the flexural strength. FA and LP can improve the resistance of compound erosion, accelerates the increase of compressive and flexural strength, which is the same with the research that strength loss were not observed of samples containing FA after erosion [21].
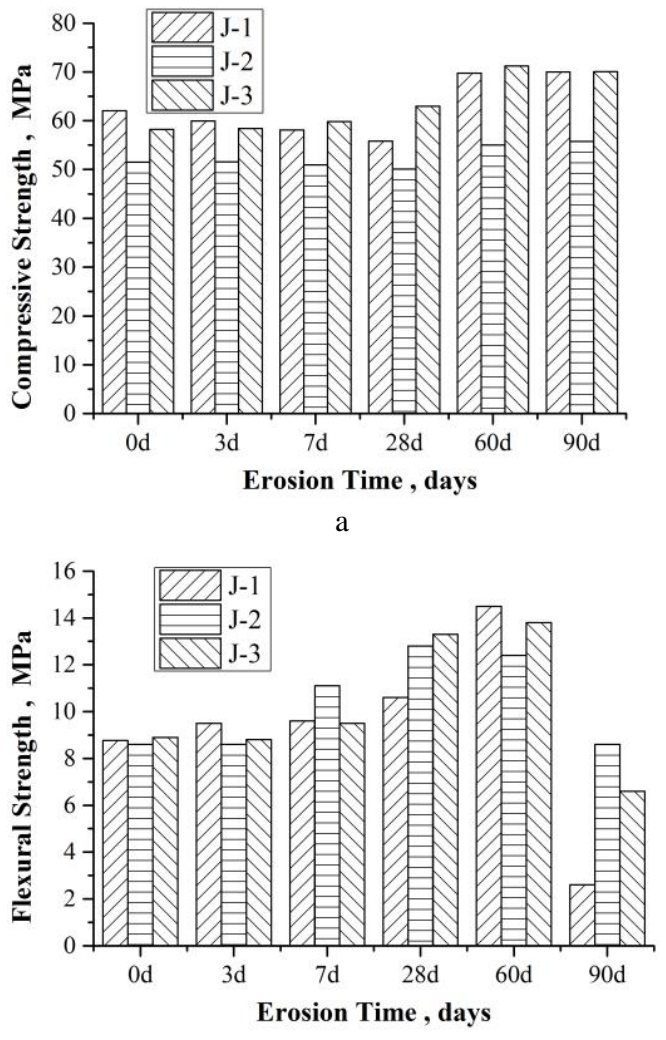

Fig. 2. Strength comparison of all pastes in compound erosion solution: a-compressive strength of all pastes; $\mathrm{b}$-flexural strength of all pastes

\subsection{Hydration products}

Fig. 3 shows the hydration products of all samples before compound erosion and at the erosion time of 28 and 90 days.

The crystal hydration products of sample J-1 (Fig. 3 a) before erosion are $\mathrm{CaCO}_{3}$ and $\mathrm{Ca}(\mathrm{OH})_{2}$, which means that there is still same LP exist and the main products are $\mathrm{Ca}(\mathrm{OH})_{2}$ after 180 days standard curing, and C-S-H gels which cannot be found in XRD analysis. After 28 days compound erosion, there is no diffraction peak of $\mathrm{Ca}(\mathrm{OH})_{2}$ and a very weak diffraction peak of $\mathrm{CaCO}_{3}$, while the diffraction peak of $\mathrm{CaSO}_{4} \cdot 2 \mathrm{H}_{2} \mathrm{O}$ is very strong. In comparison to sample $\mathrm{J}-1$, the diffraction peak intensity of $\mathrm{CaCO}_{3}$ and $\mathrm{Ca}(\mathrm{OH})_{2}$ in samples $\mathrm{J}-2$ and $\mathrm{J}-3$ are slightly stronger and the diffraction peak of $\mathrm{CaSO}_{4} \cdot 2 \mathrm{H}_{2} \mathrm{O}$ appears. It's hard to find the diffraction peaks of $\mathrm{Ca}(\mathrm{OH})_{2}$ and 
$\mathrm{CaCO}_{3}$ at 90 days erosion, while the diffraction peak intensity of $\mathrm{CaSO}_{4} \cdot 2 \mathrm{H}_{2} \mathrm{O}$ becomes stronger.
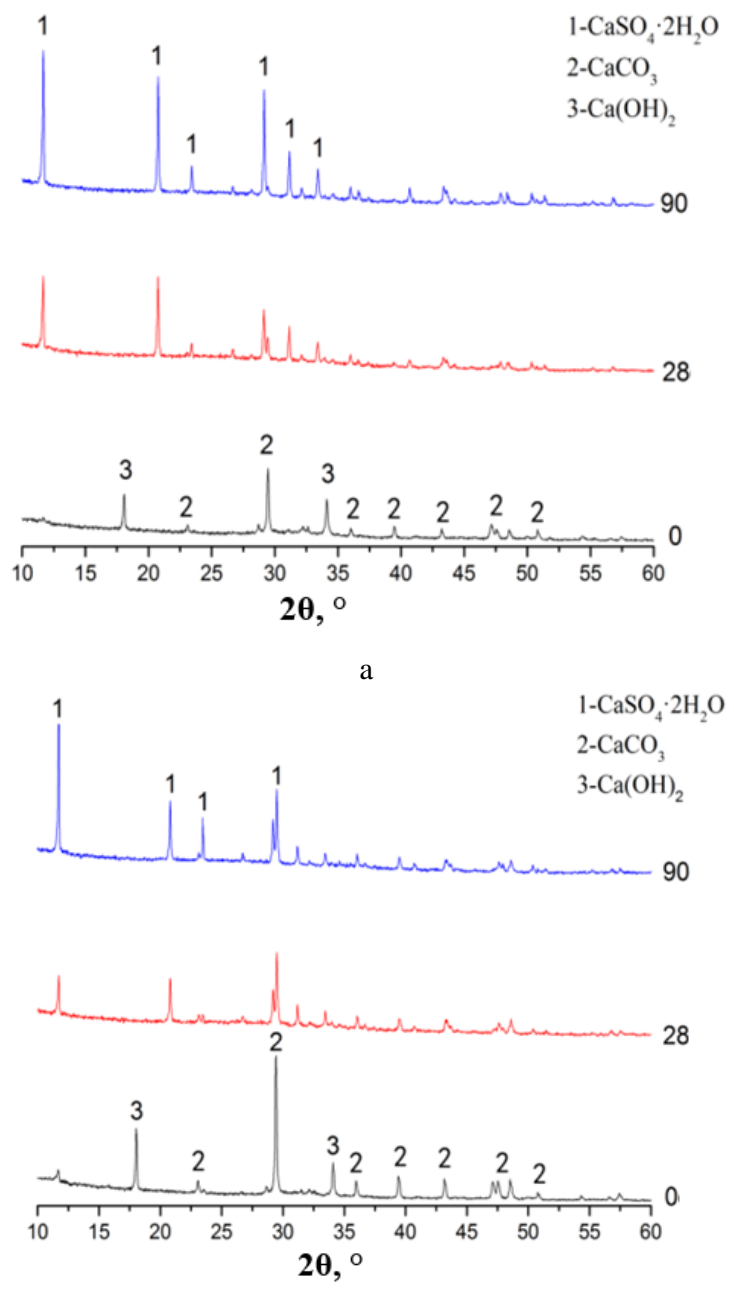

b
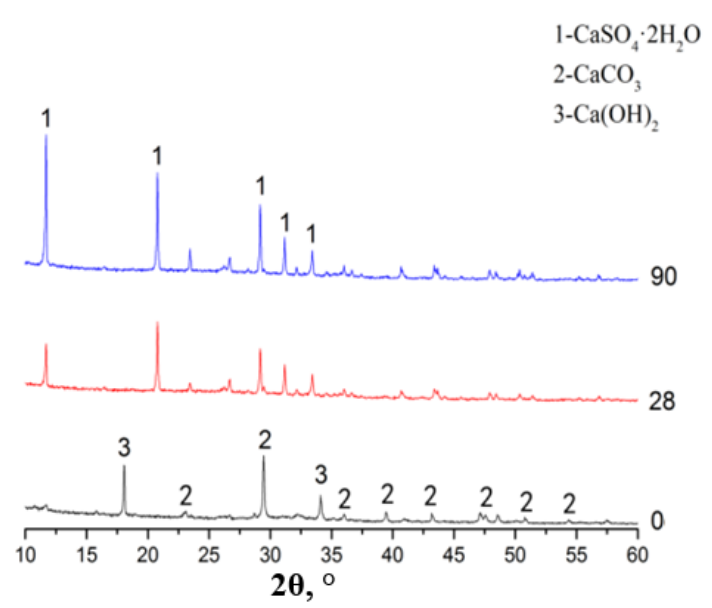

$\mathrm{c}$

Fig. 3. XRD analysis of all samples at different erosion time: $\mathrm{a}-\mathrm{XRD}$ analysis of $\mathrm{J}-1 ; \mathrm{b}-\mathrm{XRD}$ analysis of $\mathrm{J}-2 ; \mathrm{c}-\mathrm{XRD}$ analysis of $\mathrm{J}-3$

At early erosion time, neutralization happens between the hydration product $\mathrm{Ca}(\mathrm{OH})_{2}$ and the large amount of $\mathrm{H}^{+}$ ions in the erosion solution, resulting in excessive consumption of $\mathrm{Ca}(\mathrm{OH})_{2}$. Identically, some $\mathrm{CaCO}_{3}$ from LP combines with $\mathrm{H}^{+}$ions, too. Large amounts of $\mathrm{f}-\mathrm{Ca}^{2+}$ ions are released by these two chemical reactions, which can combine $\mathrm{SO}_{4}^{2-}$ ions in cement paste and generate dehydrate gypsum crystals. There is a small amount of $\mathrm{CaCO}_{3}$ subsequent to the 28 days' erosion, while after 90 days, more dehydrate gypsum crystals replace $\mathrm{Ca}(\mathrm{OH})_{2}$ and $\mathrm{CaCO}_{3}$. Some exist in the sample void, and large parts separate out of the sample surface.Fig.4 shows the TGDTA curves of all samples at different erosion time. There are two distinct endothermic peaks in DTA curves before erosion. One appears between 400 and $500{ }^{\circ} \mathrm{C}$, another appears between 700 and $800{ }^{\circ} \mathrm{C}$. According to some researches $[11,14,23]$, decomposition reaction of hydration product $\mathrm{Ca}(\mathrm{OH})_{2}$ causes the endothermic peak between 400 and $500{ }^{\circ} \mathrm{C}$, which can lose coordinated water. During the same temperature range in the TG curve, the water loss and the chemical reaction formula is as follows,

$$
\mathrm{Ca}(\mathrm{OH})_{2} \rightarrow \mathrm{CaO}+\mathrm{H}_{2} \mathrm{O} \uparrow
$$

Endothermic peak between 700 and $800{ }^{\circ} \mathrm{C}$ is due to the decomposition reaction of hydration product $\mathrm{CaCO}_{3}$. During the same temperature range in the TG curve, the water loss and the chemical reaction formula is as follows:

$\mathrm{CaCO}_{3} \rightarrow \mathrm{CaO}+\mathrm{CO}_{2} \uparrow$

After 28 days erosion, there is no endothermic peak between 400 and $500{ }^{\circ} \mathrm{C}$ in DTA curves for all samples, which indicates that no $\mathrm{Ca}(\mathrm{OH})_{2}$ exists. In compound erosion solution, a lot of $\mathrm{H}^{+}$exist, which can react with $\mathrm{Ca}(\mathrm{OH})_{2}$ and release $\mathrm{Ca}^{2+}$. Between 700 and $800{ }^{\circ} \mathrm{C}$, a very weak endothermic peak appears in the TG curve, which means little amounts of $\mathrm{CaCO}_{3}$ from LP exist. After 90 days erosion, there is no obvious endothermic peaks of sample $\mathrm{J}-1$ during these two temperature ranges. It contains no $\mathrm{Ca}(\mathrm{OH})_{2}$ and $\mathrm{CaCO}_{3}$, which all participate in the reactions. Endothermic peak happens between 100 and $200{ }^{\circ} \mathrm{C}$ when the erosion time is up to 28 and 90 days in DTA curves [11, 14, 23], which are caused by dehydration of gypsum, therefore gypsum crystals must exist, as shown in Fig. 3. Comparing to sample J-1, the endothermic peak between 700 and $800{ }^{\circ} \mathrm{C}$ in DTA curve of sample J-2 with more LP is weaker after 28 days erosion, and is the weakest after 90 days erosion. Endothermic peak happens between 100 and $200{ }^{\circ} \mathrm{C}$ when erosion age is up to 28 and 90 days in DTA curves, which is caused by dehydration of gypsum, just like sample J-1. After 28 and 90 days erosion, there is no endothermic peak between 700 and $800{ }^{\circ} \mathrm{C}$ in DTA curves, which makes it clear that there is no existence of $\mathrm{CaCO}_{3}$ in sample $\mathrm{J}-3$. Endothermic peaks appear in DTA curves between 100 and $200{ }^{\circ} \mathrm{C}$, the intensity after 90 days erosion is higher than that at 28 days.

The dehydration decompose of $\mathrm{Ca}(\mathrm{OH})_{2}$ is between 400 and $500{ }^{\circ} \mathrm{C}$, endothermic reaction to release $\mathrm{CO}_{2}$ is between 700 and $800{ }^{\circ} \mathrm{C}$, and both two chemical reactions can be expressed as for quality loss. So according to the weight loss in TG curves, the content of $\mathrm{Ca}(\mathrm{OH})_{2}$ and $\mathrm{CaCO}_{3}$ can be calculated. The results are shown in Table 3 . As the LP dosage increases, the content of $\mathrm{Ca}(\mathrm{OH})_{2}$ decreases while $\mathrm{CaCO}_{3}$ increases before the compound erosion. The content of both $\mathrm{Ca}(\mathrm{OH})_{2}$ and $\mathrm{CaCO}_{3}$ decreases with LP and FA at the same time. The content of 
$\mathrm{Ca}(\mathrm{OH})_{2}$ in any samples are 0 after 28 erosion, while the content of $\mathrm{CaCO}_{3}$ is from $13.52 \%$ to $8.33 \%$ in $\mathrm{J}-2$.

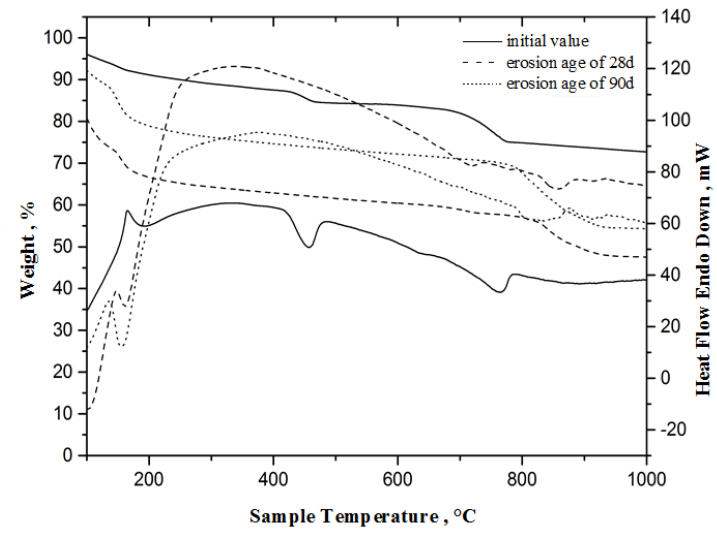

a

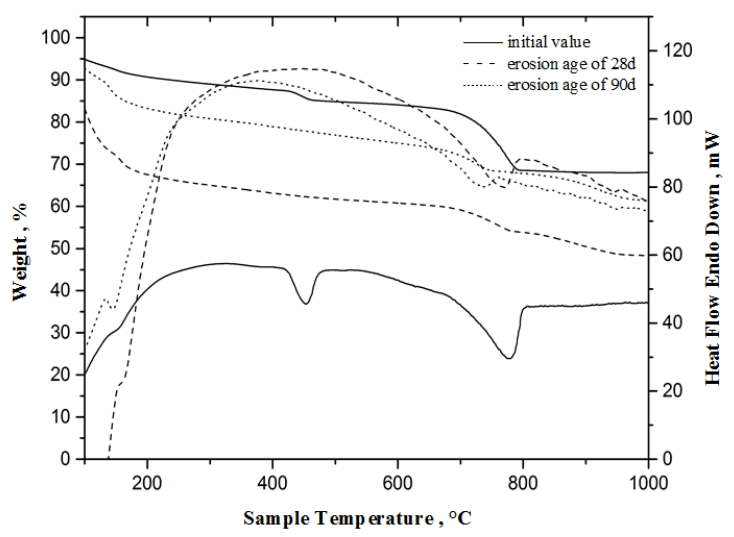

b

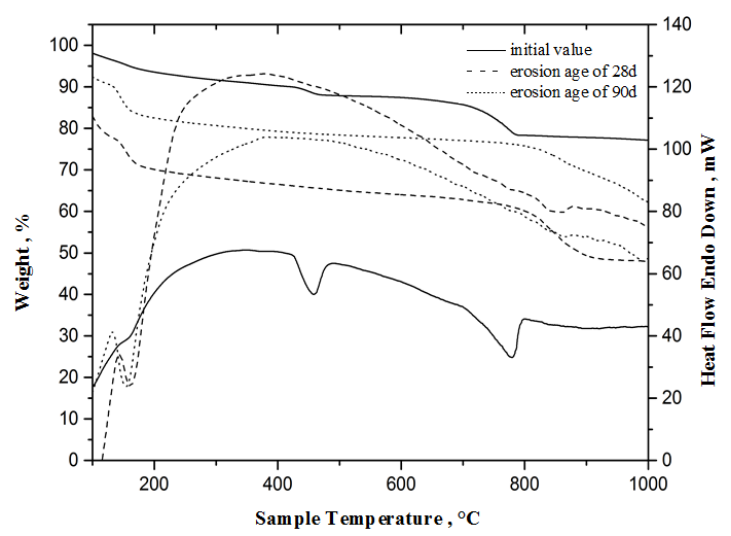

c

Fig. 4. TG-DTA curves of all samples at different erosion time: $\mathrm{a}$-TG-DTA curves of J-1;b-TG-DTA curves of J-2; c-TG-DTA curves of J-3

Table 3. The content of $\mathrm{CH}-\mathrm{Ca}(\mathrm{OH})_{2}$ and $\mathrm{CC}-\mathrm{CaCO}_{3}$ of samples at every erosion time

\begin{tabular}{|c|c|c|c|c|c|c|}
\hline \multirow{2}{*}{ Samples } & \multicolumn{2}{|c|}{ Before erosion } & \multicolumn{2}{c|}{$\begin{array}{c}\text { After } 28 \text { days } \\
\text { erosion }\end{array}$} & \multicolumn{2}{c|}{$\begin{array}{c}\text { After 90 days } \\
\text { erosion }\end{array}$} \\
\cline { 2 - 7 } & $\mathrm{CH}, \%$ & $\mathrm{CC}, \%$ & $\mathrm{CH}, \%$ & $\mathrm{CC}, \%$ & $\mathrm{CH}, \%$ & $\mathrm{CC}, \%$ \\
\hline $\mathrm{J}-1$ & 11.10 & 15.96 & 0 & 0 & 0 & 0 \\
\hline $\mathrm{J}-2$ & 10.44 & 30.01 & 0 & 13.52 & 0 & 8.33 \\
\hline $\mathrm{J}-3$ & 8.34 & 16.75 & 0 & 0 & 0 & 0 \\
\hline
\end{tabular}

Fig. 5 is the SEM micrographs of sample J-1 after 90 days soaked in different solutions. A large number of fibrous C-S-H gel can be found in Fig. 5 a, as well as the $\mathrm{CaCO}_{3}$ cubes around them. It is hard to observe $\mathrm{Ca}(\mathrm{OH})_{2}$ and $\mathrm{CaCO}_{3}$ from Fig. 5 b, while some columnar dehydrate gypsum can be found.
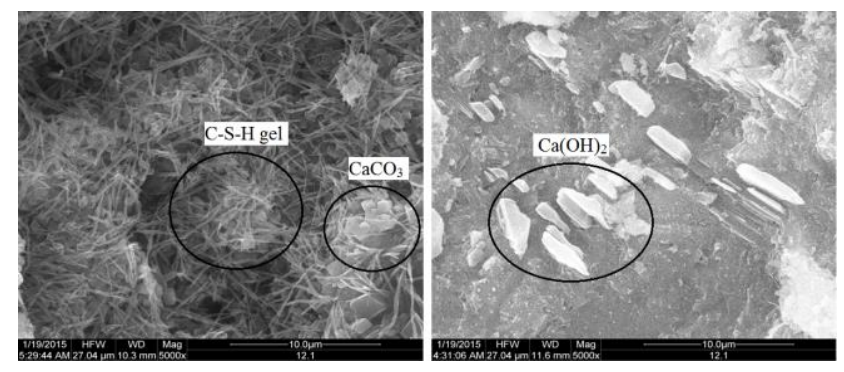

a
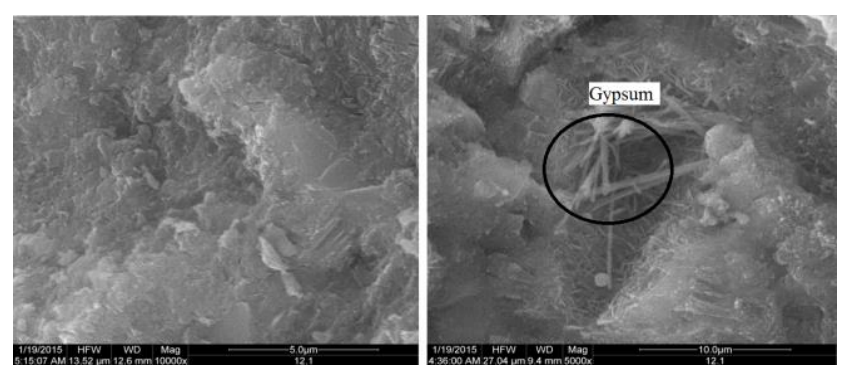

b

Fig. 5. SEM images of sample J-1 soaked in: a-saturated calcium hydroxide solution; $\mathrm{b}$-compound erosion solution

Fig. 6 is the SEM micrographs of sample J-2 after 90 days soaked in different solutions. In Fig. 6 a, a large number of mesh C-S-H gel and many $\mathrm{CaCO}_{3}$ cubes can be found. From Fig. 6 b, the structure is relatively loose and some columnar dehydrate gypsum can be observed.
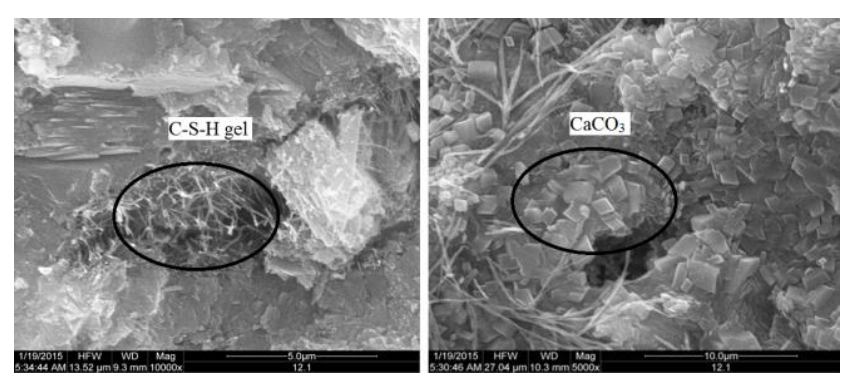

a
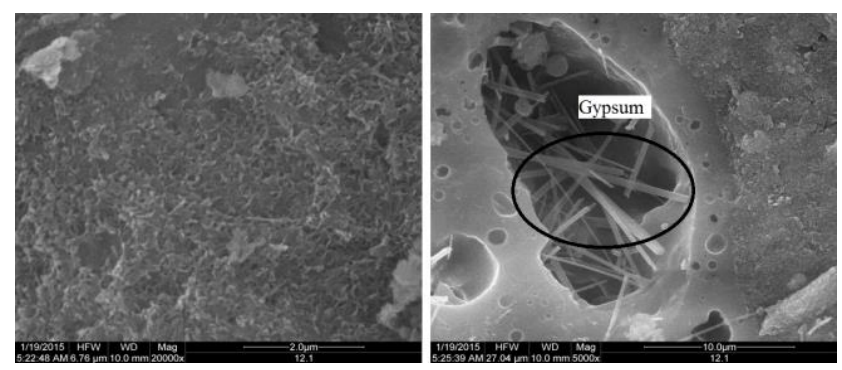

b

Fig. 6. SEM images of sample J-2 soaked in: a-saturated calcium hydroxide solution; $\mathrm{b}$-compound erosion solution 
Fig. 7 is the SEM micrographs of sample J-3 after 90 days soaked in different solutions. In Fig. 7 a, a large number of fibrous C-S-H gel and layered structure $\mathrm{Ca}(\mathrm{OH})_{2}$ can be found. From Fig. 7 b, C-S-H gel and some columnar dehydrate gypsum only can be observed.
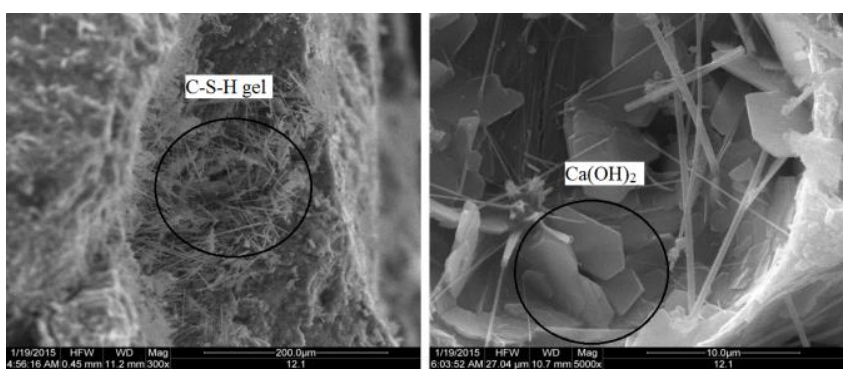

a
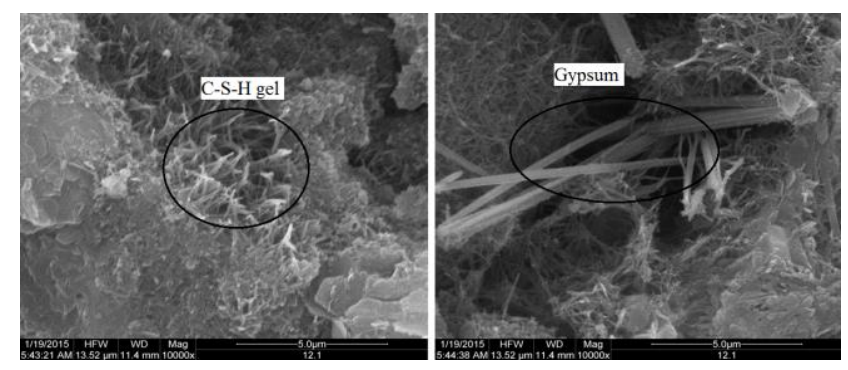

b

Fig. 7. SEM images of sample J-3 soaked in: a-saturated calcium hydroxide solution; $\mathrm{b}$-compound erosion solution

\section{CONCLUSIONS}

1. $\mathrm{H}^{+}$and $\mathrm{SO}_{4}{ }^{2-}$ ions play major roles in compound erosion solution, first is the neutralization reaction between $\mathrm{H}^{+}$ions and $\mathrm{Ca}(\mathrm{OH})_{2}$, which consumes large $\mathrm{Ca}(\mathrm{OH})_{2}$ and release lot of $\mathrm{Ca}^{2+}$; second is the combination of $\mathrm{Ca}^{2+}$ ions and $\mathrm{SO}_{4}{ }^{2-}$ ions to generate $\mathrm{CaSO}_{4} \cdot 2 \mathrm{H}_{2} \mathrm{O}$.

2. The crystal hydration products of all pastes before erosion are $\mathrm{Ca}(\mathrm{OH})_{2}$ and some $\mathrm{CaCO}_{3}$ from $\mathrm{LP}$. While after erosion, the content of $\mathrm{CaCO}_{3}$ and $\mathrm{Ca}(\mathrm{OH})_{2}$ decreases rapidly and more gypsum increases.

3. LP can reduce the compressive strength loss under compound erosion, and thus improve the erosion resistance.

\section{Acknowledgements}

This project is funded by the National Key R\&D Program of China (2016YFC0401907).

\section{REFERENCES}

1. China Cement Association. China's Cement Industry Review in 2012 and Outlook in 2013 Chinese Cement 20 2013: pp. 26-29.

2. Mehta, P.K. Reducing the Environmental Impact of Concrete Concrete International 23 2001: pp. 61-66.

3. Worrell, E., Price, L., Martin, N., Hendriks, C., Meida, L.O. Carbon Dioxide Emissions from the Global Cement Industry Annual Review of Energy and the Environment 26 2001: pp. 303-329. https://doi.org/10.1146/annurev.energy.26.1.303

4. Liu, S.H., Li, L.H. Influence of Fineness on the Cementitious Properties of Steel Slag Journal of Thermal Analysis and Calorimetry 117 2014: pp. 629-634. https://doi.org/10.1007/s10973-014-3789-0

5. Bernal, S.A., John, L. Evolution of Binder Structure in Sodium Silicate-activated Slag-metakaolin Blends Cement and Concrete Composites 33 2011: pp. 46-54.

https://doi.org/10.1016/j.cemconcomp.2010.09.004

6. Kolani, B., Buffo-Lacarrie`re, L., Sellier, A. Hydration of Slag-blended Cements Cement and Concrete Composites 34 2012: pp. 1009-1018.

https://doi.org/10.1016/j.cemconcomp.2012.05.007

7. Cai, X. Characterization of Pozzolanic Reaction and its Effect on the CSH gel in Fly Ash-cement Paste Journal of Wuhan University of Technology (Materials Science Edition) 26 2011: pp. 319-324.

https://doi.org/10.1007/s11595-011-0222-4

8. Ma, W., Brown, P.W. Hydrothermal Reactions of Fly Ash with $\mathrm{Ca}(\mathrm{OH}) 2$ and $\mathrm{CaSO}_{4} \cdot 2 \mathrm{H}_{2} \mathrm{O}$ Cement and Concrete Research 27 1997: pp. 1237-1248.

https://doi.org/10.1016/S0008-8846(97)00116-6

9. Liu, S.H., Kong, Y.N., Wang, L. A Comparison of Hydration Properties of Cement-low Quality Fly Ash Binder and Cement-limestone Powder Binder Journal of Thermal Analysis and Calorimetry 2014 116: pp. 937-943. https://doi.org/10.1007/s10973-013-3576-3

10. Weerdt, K.D., Kjellsen, K.O., Sellevold, E., Justnes, H. Synergy between Fly Ash and Limestone Powder in Ternary Cements Cement and Concrete Composites 33 2011: pp. $30-38$. https://doi.org/10.1016/j.cemconcomp.2010.09.006

11. Ye, G., Liu, X., De Schutter, G., Poppe, A.M., Taerwe, L. Influence of Limestone Powder Used as Filler in SCC on Hydration and Microstructure of Cement Pastes Cement and Concrete Composites 29 2007: pp. 94-102. https://doi.org/10.1016/j.cemconcomp.2006.09.003

12. Liu, S.H., Wang, L. Influence of Limestone Powder on Hydration Properties of Complex Binders Materials Research Innovations 18 2014: pp. 186-190. https://doi.org/10.1179/1432891714Z.000000000624

13. Liu, S.H., Yan, P.Y. Effect of Limestone Powder on Microstructure of Concrete Journal of Wuhan University of Technology (Materials Science Edition) 25 2010: pp. 328-331. https://doi.org/10.1007/s11595-010-2328-5

14. Yan, P.Y., Mi, G.D., Wang, Q. A Comparison of Early Hydration Properties of Cement-steel Slag Binder and Cement-limestone Powder Binder Journal of Thermal Analysis and Calorimetry 115 2014: pp. 193-200. https://doi.org/10.1007/s10973-013-3360-4

15. Nabil, M. Akhras, A. Durability of Metakaolin Concrete to Sulfate Attack Cement and Concrete Research 36 (9) 2006: pp. $1727-1734$. https://doi.org/10.1016/j.cemconres.2006.03.026

16. Chindaprasirt, P., Homwuttiwong, S., Sirivivatnanon, V. Influence of Fly Ash Fineness on Strength, Drying Shrinkage and Sulfate Resistance of Blended Cement Mortar Cement and Concrete Research 34 2004: pp. 1087-1092. https://doi.org/10.1016/j.cemconres.2003.11.021

17. Santhanam, M., Cohen, M.D., Olek, J. Mechanism of Sulfate Attack: A Fresh Look Cement and Concrete Research 32 2002: pp. 915-921. https://doi.org/10.1016/S0008-8846(02)00724-X 
18. Wang, X.G. Chloride Binding and Its Effects on Microstructure of Cement-based Materials Journal of the Chinese Ceramic Society 41 2013: pp. 187-198. https://doi.org/10.7521/j.issn.0454-5648.2013.02.11

19. Jung, S.H., Choi, Y.J., Lee, B.C. Influence of Carbonation on the Chloride Diffusion in Concrete. SB07 Seoul: Proceedings of the International Conference on Sustainable Building. 2007.

20. Niu, D.T., Sun, C.T. Study on Interaction of Concrete Carbonation and Chloride Corrosion Journal of the Chinese Ceramic Society 41 2013: pp. 1094-1099. https://doi.org/10.7521/j.issn.0454-5648.2013.08.11

21. Hüseyin, T., Fatih, K. Investigation of Durability of CEM II B-M Mortars and Concrete with Limestone Powder, Calcite
Powder and Fly Ash Construction and Building Materials 68 2014: pp. 517-524.

https://doi.org/10.1016/j.conbuildmat.2014.06.078

22. Davood, M., Farzaneh, N., Hamed, N.M. Influence of the Magnesium Sulphate Concentration on Durability of Concrete Containing Micro-silica, Slag and Limestone Powder using Durability Index Construction and Building Materials 117 2016: pp. 107-120.

https://doi.org/10.1016/j.conbuildmat.2016.04.091

23. Liu, S.H., Wang, L., Gap, Y.X., Yu, B.Y., Bai, Y. Comparing Study on Hydration Properties of Various Cementitious Systems Journal of Thermal Analysis and Calorimetry 118 (3) 2014: pp. 1483-1492. https://doi.org/10.1007/s10973-014-4052-4 